\title{
Dialkylboryl-Substituted Cyclic Disilenes Synthesized by Desilylation-Borylation of Trimethylsilyl-Substituted Disilenes
}

\author{
Kaho Tanaka, Naohiko Akasaka, Tomoyuki Kosai, Shunya Honda, Yuya Ushijima, Shintaro Ishida \\ and Takeaki Iwamoto *
}

check for updates

Citation: Tanaka, K.; Akasaka, N.; Kosai, T.; Honda, S.; Ushijima, Y.; Ishida, S.; Iwamoto, T. Dialkylboryl-Substituted Cyclic Disilenes Synthesized by Desilylation-Borylation of Trimethylsilyl-Substituted Disilenes. Molecules 2021, 26, 1632. https:// doi.org/10.3390/molecules26061632

Academic Editor: Myung-Hwan Whangbo

Received: 26 February 2021

Accepted: 11 March 2021

Published: 15 March 2021

Publisher's Note: MDPI stays neutral with regard to jurisdictional claims in published maps and institutional affiliations.

Copyright: (c) 2021 by the authors. Licensee MDPI, Basel, Switzerland. This article is an open access article distributed under the terms and conditions of the Creative Commons Attribution (CC BY) license (https:/ / creativecommons.org/licenses/by/ $4.0 /)$.
Department of Chemistry, Graduate School of Science, Tohoku University, 6-3 Aramakiazaaoba, Aoba-ku, Sendai 980-8578, Japan; kcahhooir0738@gmail.com (K.T.); nao.akasaka1216@gmail.com (N.A.); t.cos243@gmail.com (T.K.); shunya.honda.p8@dc.tohoku.ac.jp (S.H.); yuya.ushijima.s4@dc.tohoku.ac.jp (Y.U.); ishida@tohoku.ac.jp (S.I.)

* Correspondence: takeaki.iwamoto@tohoku.ac.jp; Tel.: +81-22-795-6558

\begin{abstract}
Electron systems of silicon have attracted attention because of their narrow HOMOLUMO gap and high reactivity, but the structural diversity remains limited. Herein, new dialkylborylsubstituted disilenes were synthesized by the selective desilylation-borylation of the corresponding trimethylsilyl-substituted disilenes. The dialkylboryl-substituted disilenes were fully characterized by a combination of NMR spectroscopy, MS spectrometry, single-crystal X-ray diffraction analysis, and theoretical calculations. The longest-wavelength absorption bands of boryldisilenes were bathochromically shifted compared to the corresponding silyl-substituted disilenes, indicating a substantial conjugation between $\pi(\mathrm{Si}=\mathrm{Si})$ and vacant $2 \mathrm{p}(\mathrm{B})$ orbitals. In the presence of 4 (dimethylamino)pyridine (DMAP), the dialkylboryl groups in the boryl-substituted disilenes were easily converted to trimethylsilyl groups, suggesting the dialkylboryl-substituted disilenes in the presence of a base serve as the surrogates of disilenyl anions (disilenides).
\end{abstract}

Keywords: borylation; desilylation; disilene; disilenide; trimethylsilyl; UV-vis spectrum; X-ray analysis

\section{Introduction}

Compounds with silicon-silicon double bonds (disilenes) have been extensively studied as $\pi$-electron systems of silicon with fascinating structural and electronic features arising from a higher-lying $\pi$ orbital and a lower-lying $\pi^{*}$ orbitals compared to those of the corresponding alkenes [1-9]. Although disilenes inherently undergo auto-oligomerization due to their weaker $\pi(\mathrm{Si}=\mathrm{Si})$ bond energy compared to the corresponding $\sigma(\mathrm{Si}-\mathrm{Si})$ bond energy, the introduction of judiciously designed bulky protecting groups enables us to synthesize a variety of isolable disilenes that contain functional groups. Among these, boryl-substituted disilenes have been less investigated compared with other functionalized disilenes (Figure 1), although the boryldisilenes are anticipated to exhibit the structure and reactivity due to the conjugation between the $\pi(\mathrm{Si}=\mathrm{Si})$ and $2 \mathrm{p}(\mathrm{B})$ orbitals and the coordination of a base to the boryl group should alter the electronic structure and reactivity. Sekiguchi et al. have shown the synthesis of boryldisilenes A-D [10-12] and the substantial interaction between the 9-borabicyclo[3.3.1]nonyl (BBN) group and the $\mathrm{Si}=\mathrm{Si}$ double bond in C. Our group has synthesized BBN-substituted disilenes E and F $[13,14]$ and found a bathochromically-shifted absorption band due to the substantial push-pull effects in disilene $\mathbf{F}$ and the activation of $\mathrm{H}_{2}$ molecule via the cleavage of the $\mathrm{Si}-\mathrm{B}$ and $\mathrm{Si}=\mathrm{Si}$ bonds. Very recently, Roesky et al. have reported boradisilacycle $\mathrm{G}$ having $2 \pi$ aromatic character [15]. Cui et al. have reported new disilene $\mathbf{H}$ [16] and disilenides $\mathbf{I}$ and $\mathbf{J}$ substituted by $\mathrm{N}$-heterocyclic boryl (NHB) groups [17].

Recently, we have developed a mild and convenient method to generate a disilenide from the corresponding stable trimethylsilyl-substituted disilene via selective cleavage of 
$\mathrm{Si}\left(\mathrm{sp}^{2}\right)-\mathrm{Si}\left(\mathrm{sp}^{3}\right)$ bond (desilylation) (Scheme 1). This method does not require a harsh reaction condition, such as the reduction with alkali metals, which have been often used for the synthesis of disilenes and disilenides (disilicon analogs of vinyl anion). This method enables us to obtain new disilenes with polycyclic aromatic hydrocarbon (PAH) groups, tetra-1,3siladienes, and a tetrasila-1,3-dienide (a silicon analog of, but-1,3-dienyl anion) [18,19]. These results prompted us to examine the synthesis of new disilenes with other functional groups. Herein, we report the synthesis of new dialkylboryl-substituted disilenes via the desilylation-borylation of trimethylsilyl-substituted disilenes, as well as their molecular structures and some reactions. Substantial interaction between the $\mathrm{Si}=\mathrm{Si}$ double bond and the dialkylboryl groups was revealed by the UV-vis spectra and TD-DFT calculations. The unprecedented substitution reactions of boryldisilenes in the presence of a base were also reported.
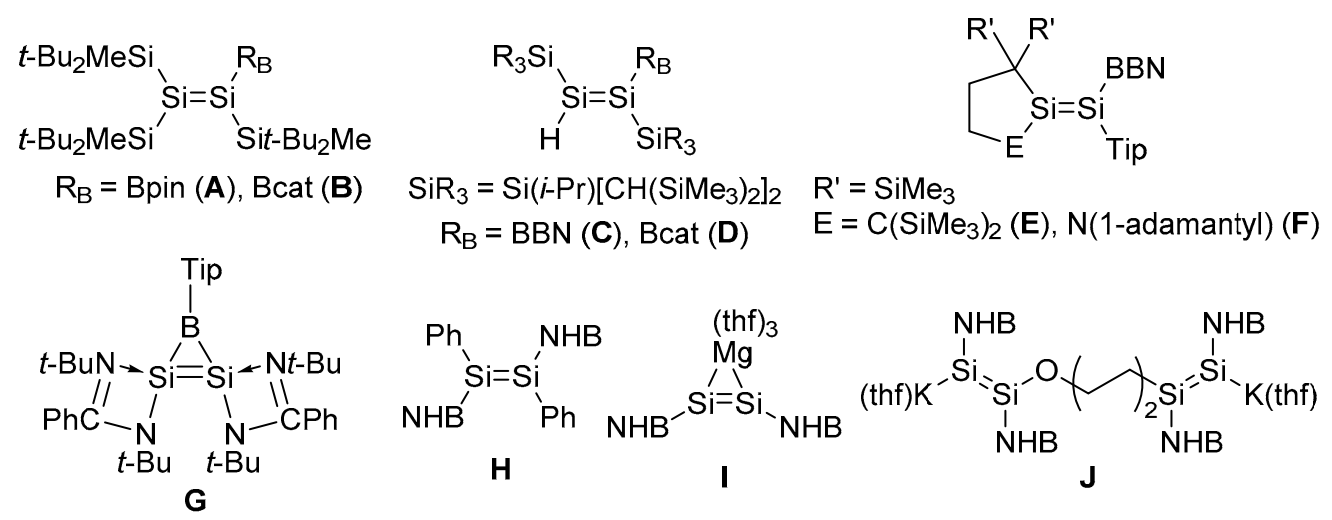

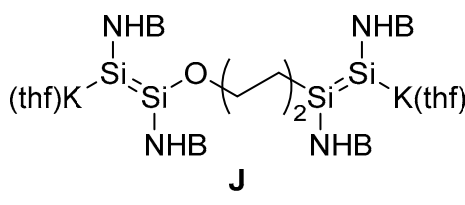

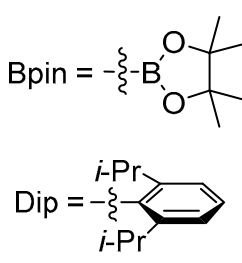

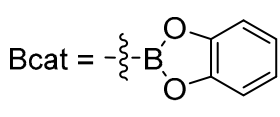

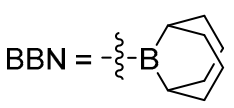

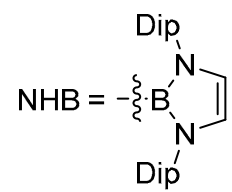
$i-\mathrm{Pr}$

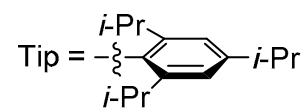

Figure 1. Reported isolable boryl-substituted disilenes.
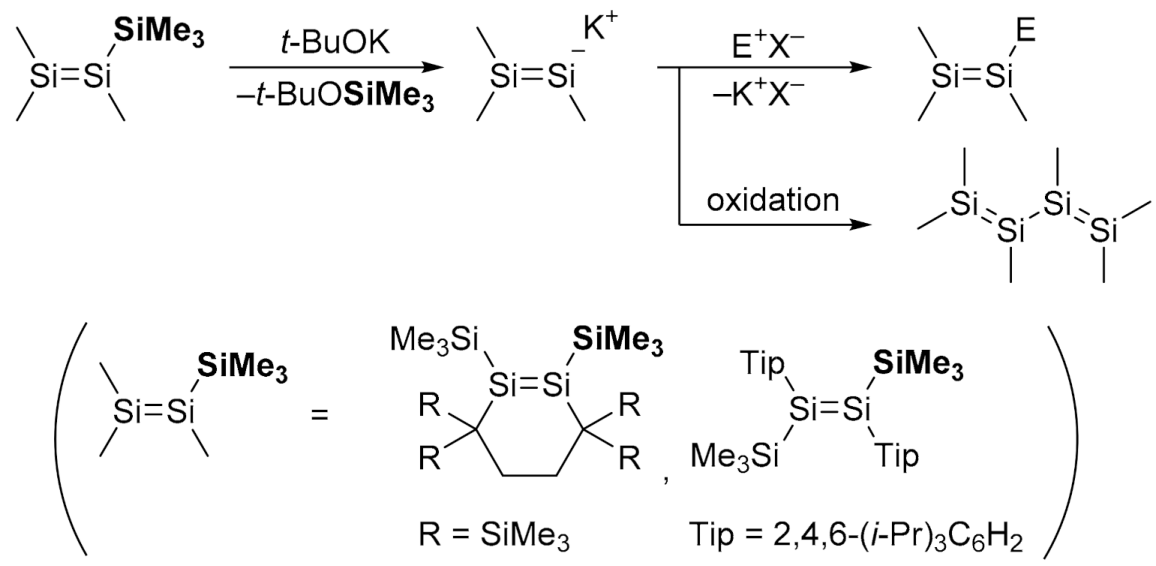

Scheme 1. Selective desilylation and subsequent reactions of trimethylsilyl-substituted disilenes. 


\section{Results and Discussion}

\subsection{Desilylation-Borylation of Silyl-Substituted Disilenes}

Monoborylated disilene 3 was obtained by the following desilylation-borylation reaction (Scheme 1). Treatment of 1,2-bis(trimethylsilyl)-1,2-disilacyclohexene $\mathbf{1}$ and one equivalent of $t$-BuOK in 1,2-dimethoxyethane (DME) lead to the quantitative formation of the corresponding disilenide 2 [19], which was confirmed by ${ }^{1} \mathrm{H}$ NMR spectroscopy. After the volatiles was removed in vacuo, the resulting residue was dissolved in dry benzene. As soon as one equivalent of 9-chloro-9-borabicyclo[3.3.1]nonane (BBNCl) was added to the benzene solution, the color of the solution turned from orange to red. After the resulting insoluble materials were filtered off and the volatiles was removed in vacuo, recrystallization from toluene provided analytically pure boryldisilene 3 as reddish-orange crystals in $61 \%$ yield (Scheme 2). Similarly, 1,2-diboryldisilene 4 was obtained as purple crystals in $56 \%$ yield from 1 by the double desilylation-borylation reactions without the isolation of 3 (Scheme 3). Notably, the desilylation by $t$-BuOK in the second step occurred selectively, although boryldisilene 3 has an electron-deficient dialkylboryl substituent as well as a $\mathrm{Si}=\mathrm{Si}$ double bond. Borylsilanes are known to react with a base, such as an alkyllithium, $\mathrm{N}$-heterocyclic carbenes, $t$-BuOK, etc. to provide the corresponding silyl anion and/or silylborate [20-24], while $t$-BuOK can add across the $\mathrm{Si}=\mathrm{Si}$ double bond in $\left(\mathrm{Me}_{3} \mathrm{Si}\right)\left(i-\mathrm{Pr}_{3} \mathrm{Si}\right) \mathrm{Si}=\mathrm{Si}\left(\mathrm{SiMe}_{3}\right)\left(\mathrm{Sii}_{-} \mathrm{Pr}_{3}\right)$ to provide the corresponding disilanyl anion [25]. The selective formation of 4 should be due to severe steric demand of a combination of the dialkylboryl group and $t$ - $\mathrm{BuO}^{-}$moiety to prohibit the coordination of $t-\mathrm{BuO}^{-}$to the boron atom, as the 4-(N,N-dimethylamino)pyridine (DMAP), which is a base with a more planar structure than $t-\mathrm{BuO}^{-}$, can coordinate the boron atom (vide infra). The structures of 3 and 4 were determined by a combination of NMR spectroscopy, MS spectrometry, elemental analyses, and single-crystal X-ray diffraction (XRD) analysis.

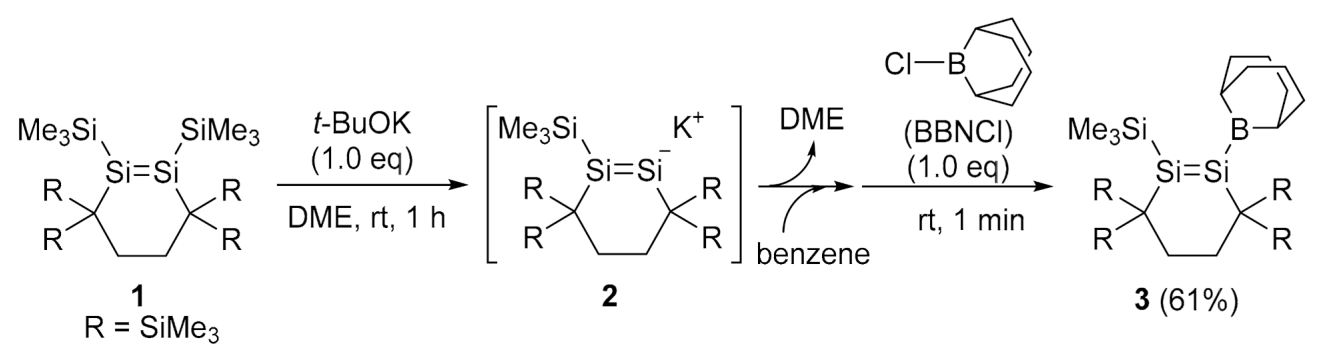

Scheme 2. Synthesis of (dialkylboryl)disilacyclohexene 3.
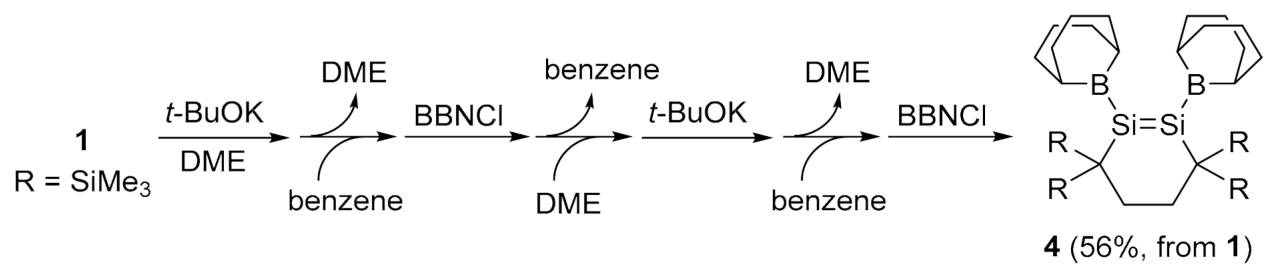

Scheme 3. Synthesis of 1,2-di(dialkylboryl)disilacyclohexene 4.

\subsection{X-ray Analysis of 3 and 4}

Molecular structures of 3 and $\mathbf{4}$ determined by single-crystal XRD analysis are shown in Figure 2, and the selected metric parameters of 3 and $\mathbf{4}$, as well as the related compounds, are shown in Table 1 . The geometries around the $\mathrm{Si}=\mathrm{Si}$ double bonds in disilenes 3 and 4 are slightly trans-bent [the trans-bent angles $\theta: 9.8^{\circ}[=\mathrm{Si}(\mathrm{BBN})]$ and $9.6^{\circ}\left(=\mathrm{SiSiMe}_{3}\right)$ as well as $4.4^{\circ}$ and $\left.8.0^{\circ}[=S i(B B N)]\right]$ and twisted [the twist angles $\tau(\mathrm{Si}=\mathrm{Si}) 19.3^{\circ}$ for 3 and $16.7^{\circ}$ for 4]. The $\mathrm{Si}=\mathrm{Si}$ distances [2.1990(8) $\AA$ and 2.2114(5) $\AA$ for 3 and 4, respectively] are longer than that of 1 [2.1762(5) $\AA$ ] with the increase of the number of dialkylboryl groups. The Si-B distances [1.994(3) $\AA$ for 3; 1.9851(14) $\AA$ and 2.0156(15) $\AA$ for 4] fall into the range of the 
Si-B distances of the reported boryl-substituted disilenes [1.945-2.022 Å] [10,11,13,14,17]. The twist angle of the $\mathrm{Si}-\mathrm{B}$ bond, $\tau(\mathrm{Si}-\mathrm{B})$, which is defined as the angle between the axis that bisects the $\mathrm{Si}\left(\mathrm{sp}^{2}\right)-\mathrm{Si}\left(\mathrm{sp}^{2}\right)-\mathrm{C}\left(\mathrm{SiMe}_{3}\right)_{2}$ angle and the axis that bisects the $\mathrm{C}-\mathrm{B}-\mathrm{C}$ angle as viewed along the $\mathrm{Si}\left(\mathrm{sp}^{2}\right)-\mathrm{B}$ axis (Table 1 ) and should qualitatively represent the dihedral angle of the $3 p$ orbital on the double bond silicon atom and the $2 p$ orbital on the boron atom, is $5.0^{\circ}$ : the orientation of the boryl group in 3 is suitable for the conjugation between the $\pi(\mathrm{Si}=\mathrm{Si})$ orbital and $2 \mathrm{p}(\mathrm{B})$ orbital. The angles $\tau(\mathrm{Si}-\mathrm{B})$ for $4\left[15.5^{\circ}(\mathrm{Si} 1)\right.$ and $\left.41.2^{\circ}(\mathrm{Si} 2)\right]$ are larger than that of $3\left(5.0^{\circ}\right)$, which would be attributed to the severe steric demand of two dialkylboryl groups.

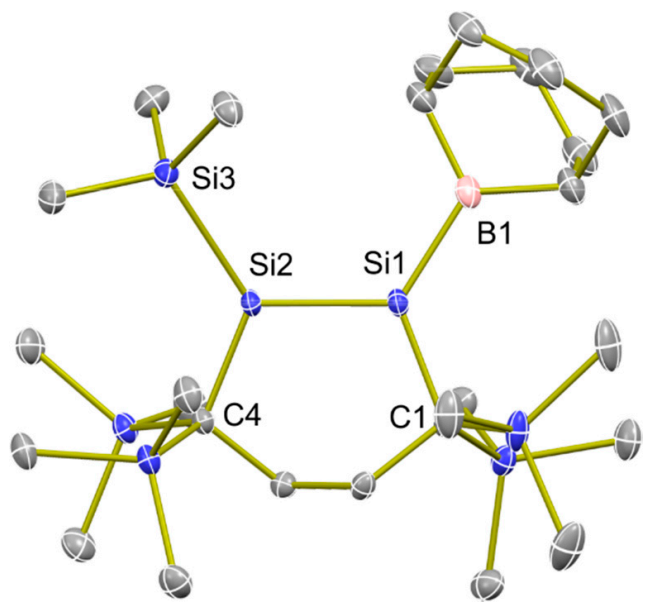

(a)

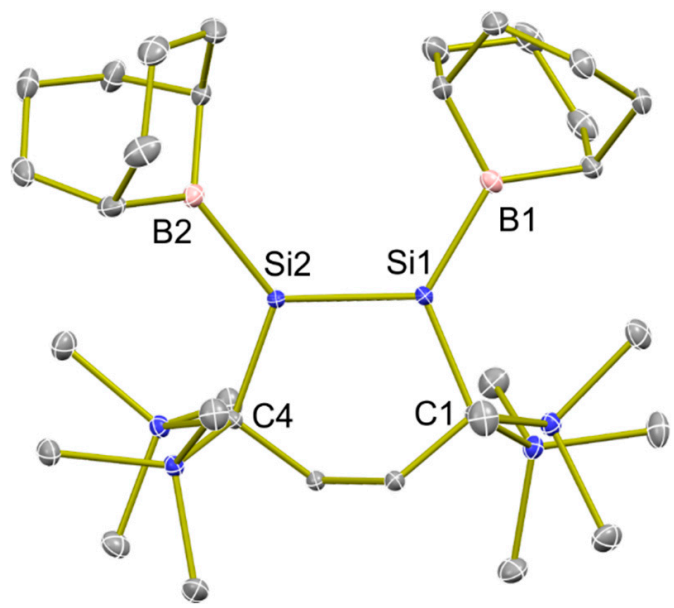

(b)

Figure 2. Molecular structures determined by single-crystal XRD analysis (atomic displacement parameters set at 50\% probability; hydrogen atoms omitted for clarity). (a) Compound 3 and (b) compound 4 .

Table 1. Selected structural parameters of 3,4, and related compounds.

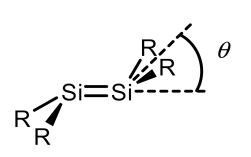

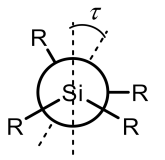

\begin{tabular}{|c|c|c|c|c|c|c|}
\hline \multirow[t]{2}{*}{ Compound } & \multicolumn{2}{|c|}{ Distance/Å } & \multicolumn{2}{|c|}{$\begin{array}{l}\text { Bent Angle } \theta /^{\circ} \\
\left(\text { Angle Sum } /{ }^{\circ} \text { ) }\right.\end{array}$} & \multicolumn{2}{|c|}{ Twist Angle $\tau /^{\circ}$} \\
\hline & $\mathrm{Si}=\mathrm{Si}$ & Si-B & Si1 & $\mathrm{Si} 2$ & $\mathrm{Si}=\mathrm{Si}$ & Si-B \\
\hline 3 & $2.1990(8)$ & $1.994(3)$ & $\begin{array}{l}9.8(\mathrm{SiBBN}) \\
(359.15(8))\end{array}$ & $\begin{array}{c}9.6 \\
\left(\mathrm{SiSiMe}_{3}\right) \\
(359.16(6))\end{array}$ & 19.3 & 5.0 \\
\hline 4 & $2.2114(5)$ & $\begin{array}{c}1.9851(14) \\
(\mathrm{Si} 1) \\
2.0156(15) \\
(\mathrm{Si} 2)\end{array}$ & $\begin{array}{c}4.4 \\
(359.83(5))\end{array}$ & $\begin{array}{c}8.0 \\
(359.36(5))\end{array}$ & 16.7 & $\begin{array}{l}15.5(\mathrm{Si} 1) \\
41.2(\mathrm{Si} 2)\end{array}$ \\
\hline 1 & $2.1762(5)$ & (" & $\begin{array}{c}12.9 \\
(358.52(3))\end{array}$ & $\begin{array}{c}6.5 \\
(359.61(3))\end{array}$ & 17.7 & - \\
\hline
\end{tabular}

\subsection{UV-Vis Spectra of $\mathbf{3}$ and $\mathbf{4}$}

Each disilene 3 and 4 exhibits a distinct absorption band in the visible region (Figure 3). The longest-wavelength absorption band maximum $\left(\lambda_{\max }\right)$ of $3(491 \mathrm{~nm})$ is bathochromically shifted by $71 \mathrm{~nm}$ relative to that of $1(420 \mathrm{~nm})$ and close to that of BBN and silylsubstituted disilene $\mathrm{C}(469 \mathrm{~nm})$ [11]. Conversely, the band shape of 4 in the visible region is different from that of 3 . Disilene 4 exhibits an absorption band at $576 \mathrm{~nm}$ with a shoul- 
der around $540 \mathrm{~nm}$. The absorption band maximum of 4 is far bathochromically shifted compared to that of monoboryldisilene 3 . The substantial bathochromic shift of the absorption band with the increase in the number of the dialkylboryl group suggests the effective conjugation between the $\mathrm{Si}=\mathrm{Si}$ double bond and the vacant $2 \mathrm{p}$ orbital(s) of the boryl group(s).

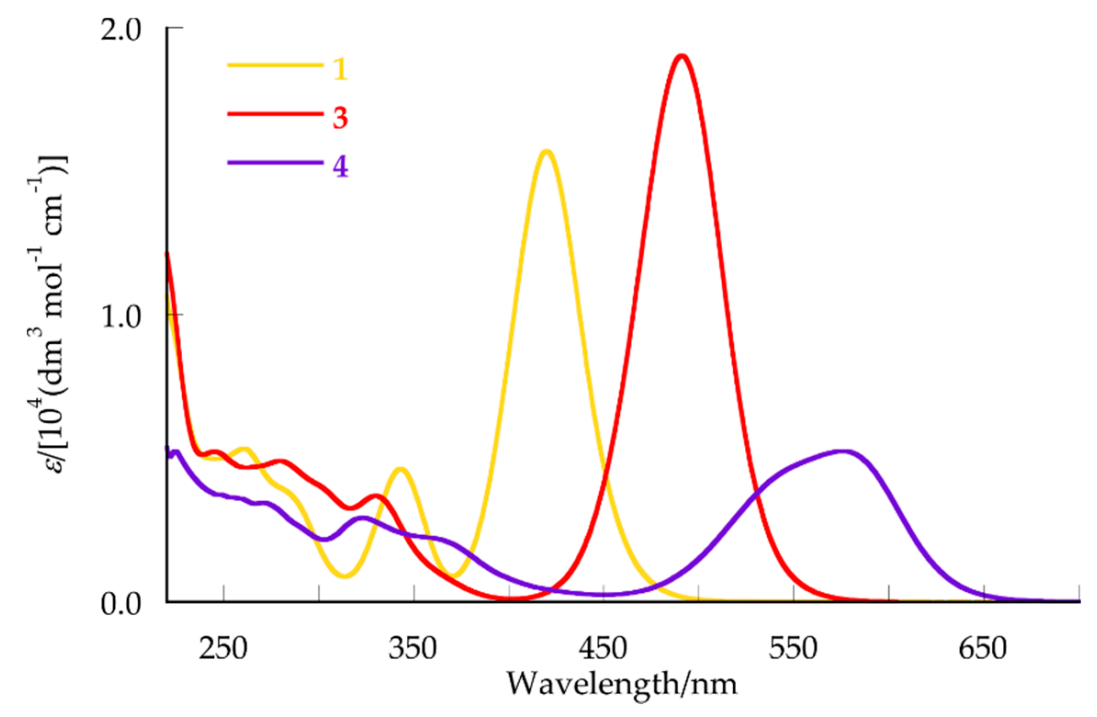

Figure 3. UV-vis spectra of disilenes 3 (reddish-orange), 4 (purple), and $\mathbf{1}$ (yellow) in hexane at room temperature.

The electronic structures of 3 and $\mathbf{4}$ were further examined by density functional theory (DFT) calculations. The structural characteristics of 3 optimized at the B3PW91D3/6-31G(d) level of theory $\left(\mathbf{3}_{\mathbf{o p t}}\right)$ are in good agreement with that obtained by XRD analysis of 3 (Table 2). The band positions and oscillator strengths of $\mathbf{3}_{\mathbf{o p t}}$ determined by TD-DFT calculations at the B3LYP/B1 level of theory (basis B1: 6-311G(2df) [Si], 6-311G(d) [other atoms]) were also consistent with those obtained from the experimental absorption spectra (Figure 4a), suggesting that the structure of 3 in solution is close to those observed in the single crystals. The HOMO of $\mathbf{3}_{\mathbf{~ o p t}}$ consists predominantly of an in-phase combination of the $\pi(\mathrm{Si}=\mathrm{Si})$ orbital and $2 \mathrm{p}(\mathrm{B})$ orbital, while the LUMO and LUMO+1 consist of an inphase and out-of-phase combination of the $\pi^{*}(\mathrm{Si}=\mathrm{Si})$ orbital and $2 \mathrm{p}(\mathrm{B})$ orbital, respectively (Figure 5). Both the HOMO [-4.79 eV] and LUMO [-2.03 eV] of $\mathbf{3}_{\mathbf{o p t}}$ are lower in energy than those of $\mathbf{1}_{\mathbf{o p t}}$ [ -4.62 and $-1.38 \mathrm{eV}$ ] due to the efficient interaction between the $\mathrm{Si}=\mathrm{Si}$ double bond and the boryl group. The HOMO-LUMO gap of $\mathbf{3}_{\mathbf{o p t}}[2.76 \mathrm{eV}]$ is smaller than that of $\mathbf{1}_{\text {opt }}[3.24 \mathrm{eV}]$, suggesting that the $2 \mathrm{p}(\mathrm{B})$ orbital should interact with the $\pi^{*}(\mathrm{Si}=\mathrm{Si})$ orbital more effectively than the $\pi(\mathrm{Si}=\mathrm{Si})$ orbital. A comparison of the experimental and theoretical spectra disclosed that the longest-wavelength absorption band of $3(491 \mathrm{~nm})$ should be attributed to the HOMO $\rightarrow$ LUMO transition. The substantial bathochromic shift of the absorption band in $\mathbf{3}$ relative to $\mathbf{1}$ should be explained by the smaller HOMO-LUMO gap resulting from the effective interaction between the $\mathrm{Si}=\mathrm{Si}$ double bond and the boryl group. In the case of $\mathbf{4}$, two conformers, conformer $1\left(4 \mathbf{a}_{\text {opt }}\right)$ and conformer $2\left(4 \mathbf{b}_{\text {opt }}\right)$, were optimized as local minima. The major structural difference between $\mathbf{4} \mathbf{a}_{\text {opt }}$ and $\mathbf{4} \mathbf{b}_{\mathbf{o p t}}$ is in the orientation of the BBN group relative to the $\mathrm{Si}=\mathrm{Si}$ double bond. The twist angles $\tau(\mathrm{Si}-\mathrm{B})$, which represents the overlap between the $3 p$ orbital on the double bond $S i$ atom and the $2 p$ orbital on the boron atom, are $8.3^{\circ}$ and 8.1 for $4 \mathbf{a}_{\text {opt }}$, while those are 13.2 and 42.6 for $4 \mathbf{b}_{\text {opt }}$, which resemble those of 4 . The geometry around the Si-B bond in $\mathbf{4} \mathbf{a}_{\text {opt }}$ is more suitable for the conjugation between the $\mathrm{Si}=\mathrm{Si}$ double bond and $2 \mathrm{p}$ orbital on the $\mathrm{B}$ atom than that of $4 \mathbf{b}_{\text {opt }}$. Although the HOMO and LUMO of $4 \mathbf{a}_{\text {opt }}$ and $4 \mathbf{b}_{\text {opt }}$ are $\pi(\mathrm{Si}=\mathrm{Si})$ and $\pi *(\mathrm{Si}=\mathrm{Si})$ orbitals with a substantial contribution of $2 \mathrm{p}(\mathrm{B})$ orbitals of two boryl groups, the HOMO and LUMO levels of $\mathbf{4} \mathbf{a}_{\mathbf{o p t}}[-4.90$ and $-2.53 \mathrm{eV}]$ are lower than those of $\mathbf{4} \mathbf{b}_{\mathbf{o p t}}[-4.86$ and 
$-2.29 \mathrm{eV}]$, which is consistent with the smaller twist angles $\tau(\mathrm{Si}-\mathrm{B})$ for $\mathbf{4} \mathbf{a}_{\text {opt }}$ compared to those of $4 \mathbf{b}_{\text {opt }}$. Compound $4 \mathbf{a}_{\text {opt }}$ is more stable by only $0.34 \mathrm{~kJ} \mathrm{~mol}^{-1}$ in free energy $(298.15 \mathrm{~K})$ than $\mathbf{4} \mathbf{b}_{\text {opt }}$, implying that both conformers can contribute to the UV-vis spectrum of 4 in solution. As expected, the observed absorption spectrum of 4 is consistent with the combined absorption bands of $\mathbf{4} \mathbf{a}_{\text {opt }}$ and $\mathbf{4} \mathbf{b}_{\text {opt }}$ obtained from the TD-DFT calculations (Figure $4 \mathrm{~b})$. The longest-wavelength absorption band of $4(576 \mathrm{~nm})$ should be attributed to the $\mathrm{HOMO} \rightarrow$ LUMO transition of $\mathbf{4} \mathbf{a}_{\mathbf{o p t}}$, and its shoulder peak $(\sim 540 \mathrm{~nm})$ should be due to the HOMO $\rightarrow$ LUMO transition of $\mathbf{4} \mathbf{b}_{\text {opt }}$. The observed UV-vis spectra of boryldisilenes 3 and 4 revealed that the BBN group effectively interacts with the $\mathrm{Si}=\mathrm{Si}$ double bond, which is consistent with the previous reports on BBN-substituted disilenes $[11,13,14]$.

Table 2. Selected structural parameters of 3, 4, and 5 calculated at the B3PW91-D3/6-31G(d) level of theory.

\begin{tabular}{|c|c|c|c|c|c|c|}
\hline \multirow{2}{*}{ Compound } & \multicolumn{2}{|c|}{ Distance/Å } & \multicolumn{2}{|c|}{$\begin{array}{l}\text { Bent Angle } \theta /^{\circ} \\
\left(\text { Angle Sum }{ }^{\circ} \text { ) }\right.\end{array}$} & \multicolumn{2}{|c|}{ Twist Angle $\tau /^{\circ}$} \\
\hline & $\mathrm{Si}=\mathrm{Si}$ & $\mathrm{Si}-\mathrm{B}$ & Si1 & $\mathrm{Si} 2$ & $\mathrm{Si}=\mathrm{Si}$ & $\mathrm{Si}-\mathrm{B}$ \\
\hline $3_{\text {opt }}$ & 2.19225 & 1.97039 & $\begin{array}{c}11.8 \\
(358.80)\end{array}$ & $\begin{array}{c}10.3 \\
(359.10)\end{array}$ & 20.2 & 2.5 \\
\hline $4 \mathbf{a}_{\text {opt }}$ & 2.20152 & $\begin{array}{c}1.98758 \\
(\mathrm{Si} 1) \\
1.99036 \\
(\mathrm{Si} 2)\end{array}$ & $\begin{array}{c}11.7 \\
(358.80)\end{array}$ & $\begin{array}{c}15.0 \\
(358.04)\end{array}$ & 27.7. & $\begin{array}{l}8.1(\mathrm{Si} 1) \\
8.3(\mathrm{Si} 2)\end{array}$ \\
\hline $4 b_{\text {opt }}$ & 2.20285 & $\begin{array}{c}1.98078 \\
(\mathrm{Si} 1) \\
2.00371 \\
(\mathrm{Si} 2)\end{array}$ & $\begin{array}{c}1.8 \\
(359.97)\end{array}$ & $\begin{array}{c}7.1 \\
(359.50)\end{array}$ & 18.9 & $\begin{array}{l}13.2(\mathrm{Si} 1) \\
42.6(\mathrm{Si} 2)\end{array}$ \\
\hline $5_{o p t}$ & 2.19009 & 2.10907 & $\begin{array}{c}10.1 \\
(359.14)\end{array}$ & $\begin{array}{c}5.4 \\
(359.69)\end{array}$ & 8.1 & - \\
\hline
\end{tabular}

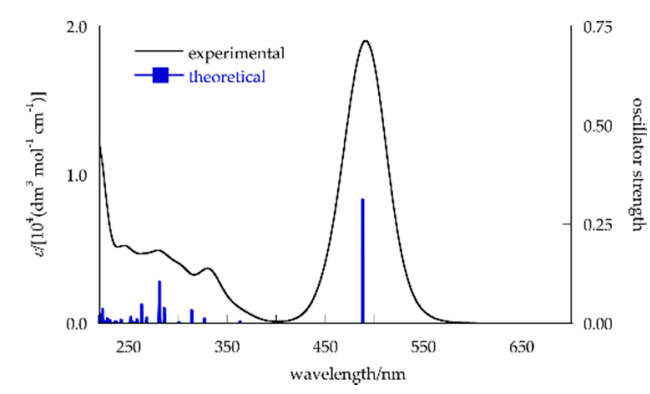

(a)

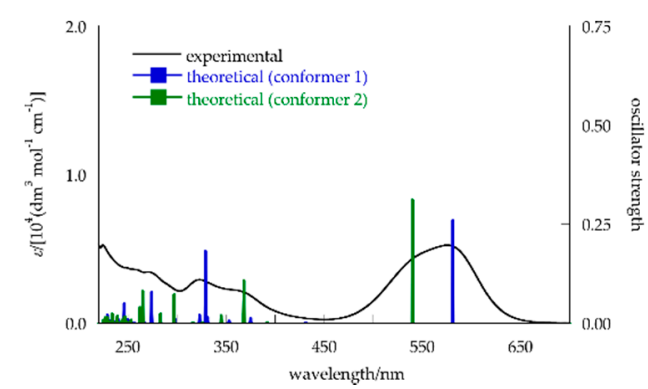

(b)

Figure 4. UV-vis spectra in hexane at room temperature and theoretical band positions and oscillator strengths (vertical bars) calculated at the B3LYP-D3/B1(hexane)//B3PW91-D3/6-31G(d) level of theory (B1: 6-311G(2df) [Si], 6-311G(d) [N, C, B, H]). (a) Compound 3 and (b) compound 4.

\subsection{Reactions of Boryldisilenes with 4-(N,N-Dimethylamino)pyridine (DMAP)}

Boryldisilene 3 reacted immediately with a typical Lewis base, 4 - $(N, N$-dimethylamino) pyridine (DMAP) at room temperature to provide DMAP-adduct 5 in $54 \%$ yield as orange crystals (Scheme 4). The structure of $\mathbf{5}$ was identified by a combination of multinuclear NMR spectra, MS spectrometry, and the preliminary single-crystal XRD analysis (Figure 6). Although it was difficult to obtain high-quality single crystals suitable for discussion of the structural parameters, the XRD analysis unequivocally revealed that DMAP coordinates to the boron atom in the solid state. DMAP coordinating to the boryl group of $\mathbf{5}$ was easily removed by $\mathrm{BPh}_{3}$ : treatment of 5 with $\mathrm{BPh}_{3}$ in $\mathrm{C}_{6} \mathrm{D}_{6}$ provided boryldisilene 3 almost quantitatively. 


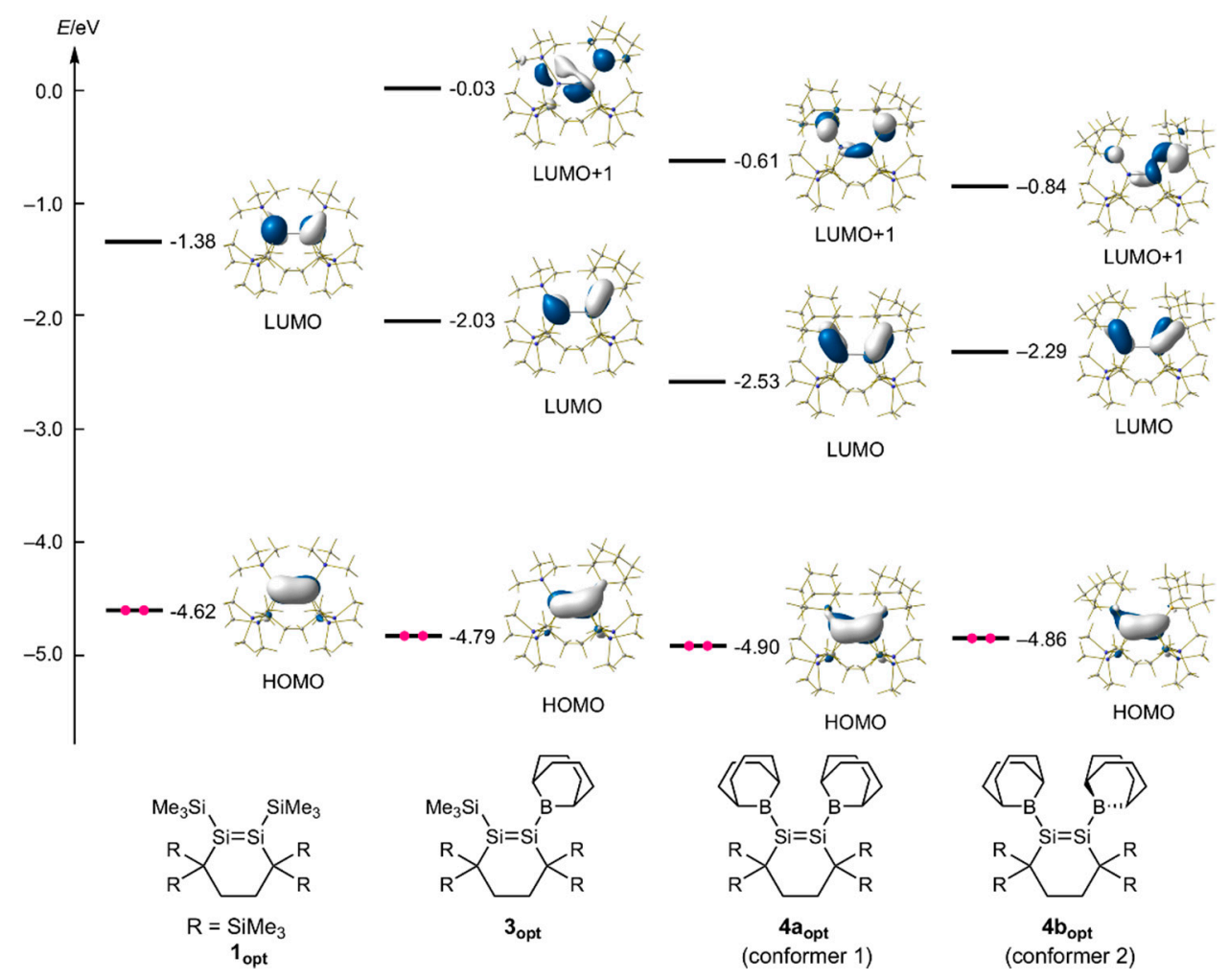

Figure 5. Frontier Kohn-Sham orbitals and their energy levels of $\mathbf{1}_{\mathbf{o p t}}, \mathbf{3}_{\mathbf{o p t}}, \mathbf{4} \mathbf{a}_{\mathbf{o p t}}$, and $\mathbf{4} \mathbf{b}_{\text {opt }}$ calculated at the B3LYP-D3/B1 level of theory (B1: 6-311G(2df) [Si], 6-311G(d) [N, C, B, H]) $\left(\mathrm{R}=\mathrm{SiMe}_{3}\right)$.
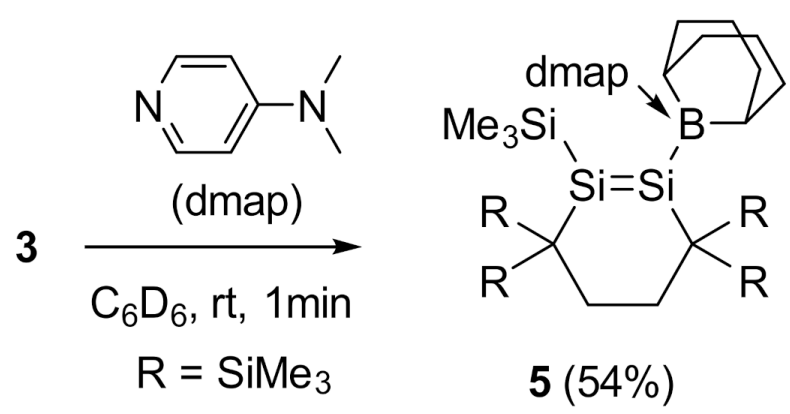

Scheme 4. Reaction of 3 and 4-(N,N-dimethylamino)pyridine (DMAP).

The UV-vis spectrum of 5 disclosed that the coordination of DMAP to the boryl group affects the electronic structure of the $\mathrm{Si}=\mathrm{Si}$ double bond. A hexane solution of $\mathbf{5}$ exhibited its longest wavelength absorption band at $418 \mathrm{~nm}$ with a shoulder band around $500 \mathrm{~nm}$ (Figure 7a). A comparison of experimental and theoretical UV-vis spectra predicted by TDDFT calculations discloses that the absorption band at 418 and the shoulder peak around $500 \mathrm{~nm}$ would be attributed to a $\pi(\mathrm{Si}=\mathrm{Si}) \rightarrow \pi^{*}(\mathrm{Si}=\mathrm{Si})$ transition and a $\pi(\mathrm{Si}=\mathrm{Si}) \rightarrow \pi^{*}(\mathrm{DMAP})$, respectively (Figure $7 \mathrm{~b})$. The $\pi(\mathrm{Si}=\mathrm{Si}) \rightarrow \pi^{*}(\mathrm{Si}=\mathrm{Si})$ transition band of $5(416 \mathrm{~nm})$ is hypsochromically shifted relative to that of boryldisilene $3(491 \mathrm{~nm})$ and comparable to that of $1(420 \mathrm{~nm})$ [19], indicating the lack of the vacant $2 p$ orbital on the boron atom resulting from the coordination of DMAP. 


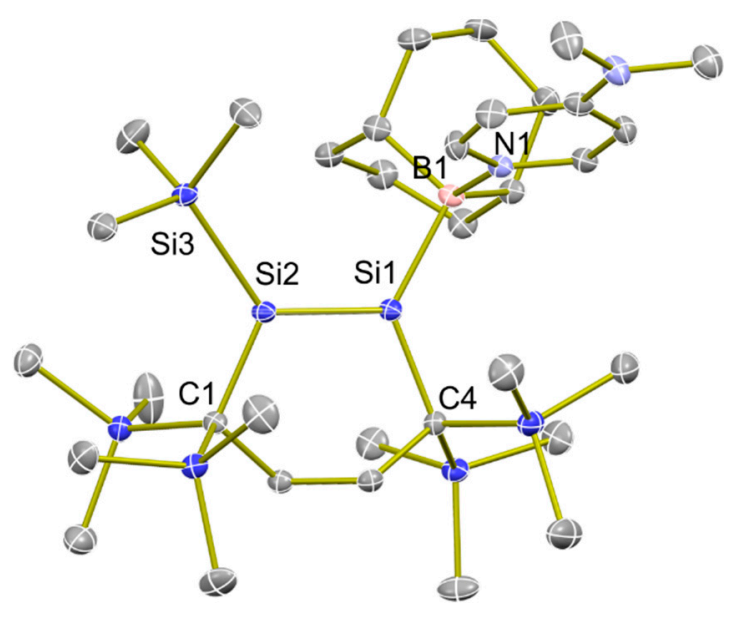

Figure 6. Preliminary XRD analysis of 5 (atomic displacement parameters set at $50 \%$ probability; hydrogen atoms omitted for clarity).

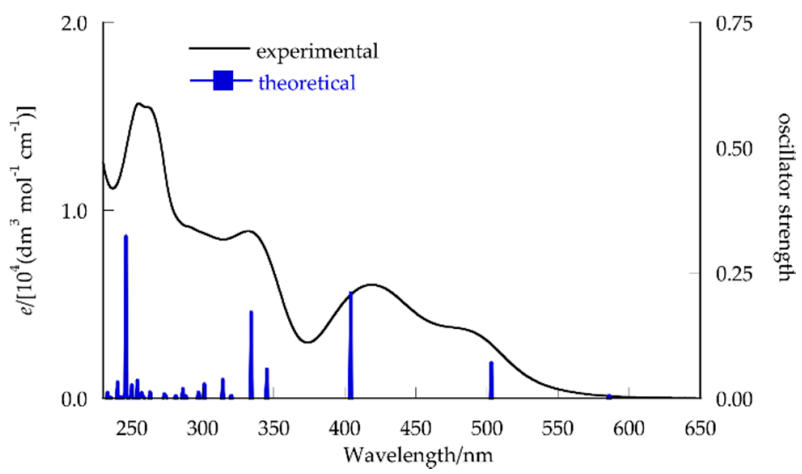

(a)

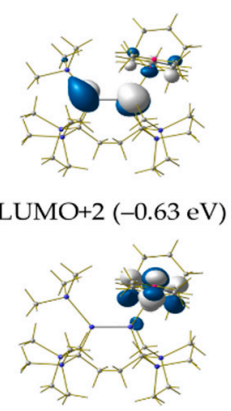

$\operatorname{LUMO}(-1.33 \mathrm{eV})$

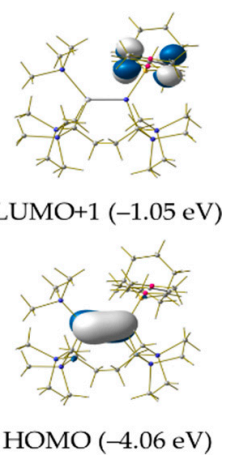

(b)

Figure 7. (a) UV-vis absorption spectrum of 5 in hexane at room temperature and theoretical band positions and oscillator strengths (vertical bars) calculated at the B3LYP-D3/B1(hexane)/ /B3PW91D3/6-31G(d) level of theory (B1: 6-311G(2df) [Si], 6-311G(d) [N, C, B, H]). (b) Selected frontier Kohn-Sham orbitals calculated at the same level.

In the ${ }^{29} \mathrm{Si} \mathrm{NMR}$ spectrum, two ${ }^{29} \mathrm{Si}$ resonances due to the unsaturated silicon nuclei [87.9 (=SiSiMe 3 ) and 195.2 (=Si(BBN.DMAP) ppm] were observed for 5 . Upon coordination of DMAP to the boryl moiety on the $\mathrm{Si}=\mathrm{Si}$ double bond, the chemical shift $(\delta \mathrm{Si})$ for the boryl-substituted double bond silicon nuclei (195.2 ppm) is substantially downfield shifted compared to that of 3 (128.7 ppm). Conversely, the $\delta \mathrm{Si}$ for the $\mathrm{SiMe}_{3}$-substituted double bond silicon nuclei $(87.9 \mathrm{ppm})$ is upfield-shifted compared to that of 3 (187.2). The substantial difference in the chemical shifts of the double bond silicon nuclei was reproduced qualitatively by the GIAO calculations of $\mathbf{5}_{\text {opt }}[73.1(=\mathrm{SiSiMe} 3)$ and 237.7 (=Si(BBN.DMAP) ppm] and $\boldsymbol{3}_{\text {opt }}$ [209.1 $\left(=\mathrm{SiSiMe}_{3}\right)$ and $136.2(=\mathrm{Si}(\mathrm{BBN}) \mathrm{ppm}]$ at the B97-D3/def2-TZVP [26] level of theory (Table S4). As Strohman, Kaupp et al. have theoretically shown that the large difference in $\delta \mathrm{Si}$ of the double bond Si nuclei in the unsymmetrically substituted disilenes is mainly due to the spatial extent and orientation of the occupied and unoccupied molecular orbitals around the $\mathrm{Si}=\mathrm{Si}$ double bond [27], the remarkable change in the $\delta \mathrm{Si}$ of the double bond Si nuclei upon coordination of DMAP is consistent with the lack of the conjugation between the $\pi(\mathrm{Si}=\mathrm{Si})$ and $2 \mathrm{p}(\mathrm{B})$ orbitals.

Notably, treatment of 5 with $\mathrm{Me}_{3} \mathrm{SiCl}$ in benzene- $d_{6}$ at $60{ }^{\circ} \mathrm{C}$ for $3 \mathrm{~h}$ provided disilene 1 in $66 \%$ yield (Scheme 5), indicating that the DMAP-coordinated boryl group on the double bond silicon atom was substituted by $\mathrm{SiMe}_{3}$ group. In this reaction, 5 formally serves as a disilenide like 2. As the reaction of boryldisilene 3 and $\mathrm{Me}_{3} \mathrm{SiCl}$ does not 
proceed in benzene- $d_{6}$ at $60{ }^{\circ} \mathrm{C}$, the coordination of DMAP to the boryl group is crucial for this substitution reaction, similar to the reactions of pinacolboryl-substituted silanes, which can work as silyl nucleophiles in the presence of a base [20-24]. Similar substitution reaction occurred upon treatment of diboryldisilene 4 with DMAP (2 equiv) followed by $\mathrm{Me}_{3} \mathrm{SiCl}$ (Scheme 6) to provide 1 in $43 \%$ in two steps, although the characterization of the intermediates of this reaction has been unsuccessful due to the unresolved broad NMR signals. The observed reactions suggest a boryl-substituted disilene can be a synthetic equivalent of a disilenyl anion (a disilenide) in the presence of a Lewis base.

5

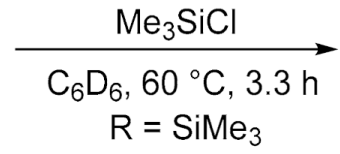

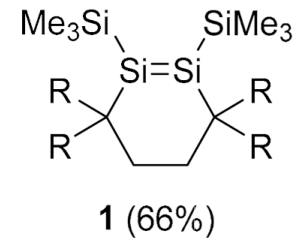

Scheme 5. Reaction of 5 with $\mathrm{Me}_{3} \mathrm{SiCl}$.

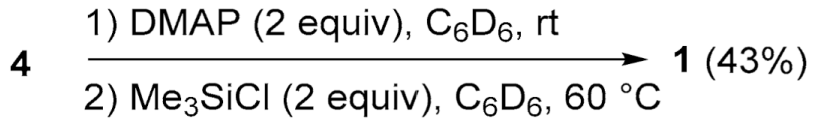

Scheme 6. Reaction of 4 with DMAP (2 equiv) followed by $\mathrm{Me}_{3} \mathrm{SiCl}$ (2 equiv).

\section{Conclusions}

We successfully synthesized dialkylboryl-substituted cyclic disilenes 3 and 4 by the desilylation-borylation of the corresponding 1,2-bis(trimethylsilyl)-substituted cyclic disilene 1. The effective conjugation between the $\mathrm{Si}=\mathrm{Si}$ double bond and the dialkylboryl group is reflected in a substantial bathochromic shift of the longest-wavelength absorption band. 4-(N,N-Dimethylamino)pyridine (DMAP) coordinates to the boryl group of monoboryldisilene 3 to afford the corresponding boranuidyldisilene 5 . The DMAP-coordinated boryl group in 5 was converted to the $\mathrm{Me}_{3} \mathrm{Si}$ group after treatment with $\mathrm{Me}_{3} \mathrm{SiCl}$. In the presence of 2 equiv of DMAP, diboryldisilene 4 also undergoes a similar substitution reaction to afford 1,2-bis(trimethylsilyl)disilene 1 . These results imply that boryl-substituted disilenes have the potential to serve as surrogates of disilenides in the presence of an appropriate base.

\section{Materials and Methods}

\subsection{General Procedure}

All reactions treating air-sensitive compounds were performed under argon or nitrogen atmosphere using a high-vacuum line, standard Schlenk techniques, or a glove box, as well as dry and oxygen-free solvents. ${ }^{1} \mathrm{H}(500 \mathrm{MHz}),{ }^{11} \mathrm{~B}(160 \mathrm{MHz}),{ }^{13} \mathrm{C}(125 \mathrm{MHz})$, and ${ }^{29} \mathrm{Si}(99 \mathrm{MHz})$ NMR spectra were recorded on a Bruker Avance III 500 FT NMR spectrometer. The ${ }^{1} \mathrm{H}$ NMR chemical shifts in benzene- $d_{6}\left(\mathrm{C}_{6} \mathrm{D}_{6}\right)$ were referenced to the residual $\mathrm{C}_{6} \mathrm{D}_{5} \mathrm{H}$ signal $\left(\delta\right.$ 7.16). The ${ }^{13} \mathrm{C}\left\{{ }^{1} \mathrm{H}\right\}$ and ${ }^{29} \mathrm{Si}\left\{{ }^{1} \mathrm{H}\right\}$ NMR chemical shifts were relative to $\mathrm{Me}_{4} \mathrm{Si}(\delta 0.00)$. The ${ }^{11} \mathrm{~B} \mathrm{NMR}$ chemical shifts were relative to $\mathrm{BF}_{3} \cdot \mathrm{OEt}_{2}(\delta 0.00)$. Sampling of air-sensitive compounds was carried out using a VAC NEXUS 100027-type glove box. Mass spectra were recorded on a Bruker Daltonics SolariX 9.4T or a JEOL JMS-Q1050 spectrometer. UV-vis spectra were recorded on a JASCO V-660 spectrometer.

\subsection{Materials}

Benzene, hexane, tetrahydrofuran (THF), and toluene were dried by using a VAC (Vacuum Atmospheres Company) solvent purifier 103991. 1,2-Dimethoxyethane (DME) and toluene- $d_{8}$ were dried over $\mathrm{LiAlH}_{4}$ or potassium mirror and then distilled prior to use through a vacuum line. Benzene- $d_{6}$ was degassed and dried over molecular sieves 
(4Å). Disilene 1 [19] and 9-chloro-9-borabicyclo[3.3.1]nonane (BBNCl) [28] were prepared according to the procedure described in the literature. Chlorotrimethylsilane, 4- $(\mathrm{N}, \mathrm{N}$ dimethylamino)pyridine (DMAP), and potassium $t$-butoxide $(t$-BuOK) were purchased from commercial sources and used without further purification.

\subsection{Synthesis of (Dialkylboryl)disilene 3}

In a Schlenk tube (50 mL) equipped with a magnetic stir bar, disilene $1(134 \mathrm{mg}$, $\left.2.45 \times 10^{-1} \mathrm{mmol}\right), t$-BuOK $\left(28.9 \mathrm{mg}, 2.58 \times 10^{-1} \mathrm{mmol}\right)$ and DME $(9.0 \mathrm{~mL})$ was placed. After stirring the mixture for $1 \mathrm{~h}$ at room temperature, disilenide 2 was formed as a sole product, which was confirmed by ${ }^{1} \mathrm{H}$ NMR spectroscopy. Then DME was removed in vacuo; the resulting residue was dissolved in benzene $(12 \mathrm{~mL})$. To the solution, a benzene solution (3.0 mL) of 9-chloro-9-borabicyclo[3.3.1]nonane (BBNCl) $\left(38.4 \mathrm{mg}, 2.45 \times 10^{-1}\right.$ $\mathrm{mmol}$ ) was added, and the mixture was stirred for $1 \mathrm{~min}$ at room temperature. The resulting insoluble materials were filtered off and washed with benzene. The volatiles was removed from the filtrate in vacuo. Recrystallization from hexane at $-35^{\circ} \mathrm{C}$ provided boryldisilene 3 as reddish-orange crystals $\left(89.0 \mathrm{mg}, 1.50 \times 10^{-1} \mathrm{mmol}\right)$ in $61 \%$ yield. Single crystals suitable for X-ray diffraction analysis were obtained by recrystallization from toluene at room temperature.

3: reddish-orange crystals; mp. $103{ }^{\circ} \mathrm{C}$ (decomp); ${ }^{1} \mathrm{H}$ NMR $\left(\mathrm{C}_{6} \mathrm{D}_{6}, 500 \mathrm{MHz}, 295 \mathrm{~K}\right) \delta$ $0.21\left(\mathrm{~s}, 9 \mathrm{H}, \mathrm{Si}\left(\mathrm{CH}_{3}\right)_{3}\right), 0.29$ (s, 9H, Si $\left.\left(\mathrm{CH}_{3}\right)_{3}\right), 0.34\left(\mathrm{~s}, 9 \mathrm{H}, \mathrm{Si}\left(\mathrm{CH}_{3}\right)_{3}\right), 0.38\left(\mathrm{~s}, 9 \mathrm{H}, \mathrm{Si}\left(\mathrm{CH}_{3}\right)_{3}\right)$, $0.48\left(\mathrm{~s}, 9 \mathrm{H}, \mathrm{Si}\left(\mathrm{CH}_{3}\right)_{3}\right), 1.41-1.49(\mathrm{~m}, 2 \mathrm{H}, \mathrm{BBN}), 1.90-2.11\left(\mathrm{~m}, 12 \mathrm{H}, \mathrm{BBN}+\mathrm{CH}_{2}\right), 2.49$ (brs, 2H, BBN), 2.52-2.60 (m, 2H, CH 2$) ;{ }^{13} \mathrm{C}$ NMR $\left(\mathrm{C}_{6} \mathrm{D}_{6}, 125 \mathrm{MHz}, 296 \mathrm{~K}\right) \delta 1.0\left(\mathrm{Si}\left(\mathrm{CH}_{3}\right)_{3}\right), 1.2$ $\left(\mathrm{Si}\left(\mathrm{CH}_{3}\right)_{3}\right), 3.9\left(\mathrm{Si}\left(\mathrm{CH}_{3}\right)_{3}\right), 4.29\left(\mathrm{Si}\left(\mathrm{CH}_{3}\right)_{3}\right), 4.34\left(\mathrm{Si}\left(\mathrm{CH}_{3}\right)_{3}\right), 20.7(\mathrm{C}), 23.7\left(\mathrm{CH}_{2}\right), 26.6(\mathrm{C})$, $33.5(2 \times \mathrm{CH}), 34.5\left(\mathrm{CH}_{2}\right), 34.69\left(\mathrm{CH}_{2}\right), 34.72\left(\mathrm{CH}_{2}\right), 35.6\left(\mathrm{CH}_{2}\right) ;{ }^{29} \mathrm{Si}$ NMR $\left(\mathrm{C}_{6} \mathrm{D}_{6}, 99 \mathrm{MHz}\right.$, $295 \mathrm{~K}) \delta-10.0\left(\mathrm{SiMe}_{3}\right), 0.2\left(\mathrm{SiMe}_{3}\right), 1.1\left(\mathrm{SiMe}_{3}\right), 1.6\left(\mathrm{SiMe}_{3}\right), 1.8\left(\mathrm{SiMe}_{3}\right), 128.7$ (=SiBBN), 187.2 [ $\left.=\mathrm{SiSiMe}_{3}\right] ;{ }^{11} \mathrm{~B}$ NMR $\left(\mathrm{C}_{6} \mathrm{D}_{6}, 160 \mathrm{MHz}, 295 \mathrm{~K}\right) \delta 92.1$; UV-vis (hexane) $\lambda_{\max } / \mathrm{nm}(\varepsilon)$ $490\left(1.9 \times 10^{4}\right)$; MS (EI, $\left.70 \mathrm{eV}\right) \mathrm{m} / z(\%) 594\left(3.8, \mathrm{M}^{+}\right), 521\left(7.0, \mathrm{M}^{+}-\mathrm{SiMe}_{3}\right)$; Anal. Calcd for $\mathrm{C}_{27} \mathrm{H}_{63} \mathrm{BSi}_{7}$ : $\mathrm{C}, 54.48 ; \mathrm{H}, 10.67 \%$. Found: $\mathrm{C}, 54.30 ; \mathrm{H}, 10.62 \%$.

\subsection{Synthesis of 1,2-Di(dialkylboryl)disilene 4}

In a Schlenk tube (50 mL) equipped with a magnetic stir bar, disilene $1(249 \mathrm{mg}$, $\left.4.56 \times 10^{-1} \mathrm{mmol}\right), t$-BuOK $\left(51.6 \mathrm{mg}, 4.60 \times 10^{-1} \mathrm{mmol}\right)$, and DME $(30 \mathrm{~mL})$ were placed. After stirring for $1 \mathrm{~h}$ at room temperature, disilenide 2 was formed as a sole product, which was confirmed by ${ }^{1} \mathrm{H}$ NMR spectroscopy. Then DME was removed in vacuo; the resulting residue was dissolved in benzene $(29 \mathrm{~mL})$. To the solution, a benzene solution $(0.5 \mathrm{~mL})$ of 9-chloro-9-borabicyclo[3.3.1]nonane (BBNCl) $\left(72.1 \mathrm{mg}, 4.61 \times 10^{-1} \mathrm{mmol}\right)$ was added, and the mixture was stirred for $1 \mathrm{~min}$ at room temperature. Then the volatiles was removed in vacuo; the resulting residue was dissolved in DME $(12 \mathrm{~mL})$. To the solution, $t-\mathrm{BuOK}$ (51.1 mg, $4.55 \times 10^{-1} \mathrm{mmol}$ ) was added, and the mixture was stirred for $1 \mathrm{~min}$ at room temperature. Then the volatiles was removed in vacuo; the resulting residue was dissolved in benzene $(14 \mathrm{~mL})$ again. To the solution, a benzene solution $(0.5 \mathrm{~mL})$ of $\mathrm{BBNCl}(71.2 \mathrm{mg}$, $4.55 \times 10^{-1} \mathrm{mmol}$ ) was added, and the mixture was stirred for $1 \mathrm{~min}$ at room temperature. The resulting insoluble materials were filtered off and washed with benzene, and then the volatiles was removed from the filtrate in vacuo. The formation of 1,2-diboryldisilene 4 as a major product was confirmed by the ${ }^{1} \mathrm{H}$ NMR spectrum. Recrystallization from hexane at $-35^{\circ} \mathrm{C}$ gave 4 as purple crystals $\left(164 \mathrm{mg}, 2.55 \times 10^{-1} \mathrm{mmol}\right)$ in $56 \%$ yield. Singles crystal suitable for $\mathrm{X}$-ray diffraction analysis were obtained by recrystallization from toluene at room temperature.

4: purple crystals; mp. $106{ }^{\circ} \mathrm{C}$ (decomp); ${ }^{1} \mathrm{H}$ NMR $\left(\mathrm{C}_{6} \mathrm{D}_{6}, 500 \mathrm{MHz}, 297 \mathrm{~K}\right) \delta 0.27$ (s, $\left.18 \mathrm{H}, \mathrm{Si}\left(\mathrm{CH}_{3}\right)_{3}\right), 0.39\left(\mathrm{~s}, 18 \mathrm{H}, \mathrm{Si}\left(\mathrm{CH}_{3}\right)_{3}\right), 1.38-1.45(\mathrm{~m}, 4 \mathrm{H}, \mathrm{BBN}), 1.96-2.11(\mathrm{~m}, 22 \mathrm{H}, \mathrm{BBN}$, overlapping with $\left.\mathrm{CH}_{2} \mathrm{CH}_{2}\right), 2.57-2.63\left(\mathrm{~m}, 6 \mathrm{H}, \mathrm{BBN}\right.$, overlapping with $\left.\mathrm{CH}_{2} \mathrm{CH}_{2}\right) ;{ }^{13} \mathrm{C} \mathrm{NMR}$ $\left(\mathrm{C}_{6} \mathrm{D}_{6}, 125 \mathrm{MHz}, 297 \mathrm{~K}\right) \delta 1.4\left(\mathrm{Si}\left(\mathrm{CH}_{3}\right)_{3}\right), 4.5\left(\mathrm{Si}\left(\mathrm{CH}_{3}\right)_{3}\right), 23.6\left(\mathrm{CH}_{2}\right), 25.3(\mathrm{C}), 34.5\left(\mathrm{CH}_{2}\right)$, $34.86\left(\mathrm{CH}_{2}\right), 34.94$ (two BBN-CH), $35.3\left(\mathrm{CH}_{2}\right) ;{ }^{29} \mathrm{Si} \mathrm{NMR}\left(\mathrm{C}_{6} \mathrm{D}_{6}, 99 \mathrm{MHz}, 297 \mathrm{~K}\right) \delta 0.5$ ( $\left.\mathrm{SiMe}_{3}\right), 2.0\left(\mathrm{SiMe}_{3}\right), 166.2(\mathrm{Si}=\mathrm{Si}),{ }^{11} \mathrm{~B} \mathrm{NMR}\left(\mathrm{C}_{6} \mathrm{D}_{6}, 160 \mathrm{MHz}, 296 \mathrm{~K}\right) \delta 93.7$; UV-vis (hexane) 
$\lambda_{\max } / \mathrm{nm}(\varepsilon) 576\left(5.3 \times 10^{3}\right), 550(\mathrm{sh}) ; \mathrm{MS}(\mathrm{EI}, 70 \mathrm{eV}) \mathrm{m} / \mathrm{z}(\%) ; 642\left(2.0, \mathrm{M}^{+}\right), 569(1.1$, $\mathrm{M}^{+}-\mathrm{SiMe}_{3}$ ); Anal. Calcd for $\mathrm{C}_{32} \mathrm{H}_{68} \mathrm{~B}_{2} \mathrm{Si}_{6}$ : C, 59.77; H, 10.66\%. Found: C, 59.41; H, 10.80\%.

\subsection{Synthesis of Boryldisilene-DMAP Complex 5}

In a J. Young NMR tube, boryldisilene $3\left(43.3 \mathrm{mg}, 7.27 \times 10^{-2} \mathrm{mmol}\right), 4-(\mathrm{N}, \mathrm{N}$ dimethylamino)pyridine $\left(10.4 \mathrm{mg}, 8.51 \times 10^{-2} \mathrm{mmol}\right)$, and $\mathrm{C}_{6} \mathrm{D}_{6}(0.7 \mathrm{~mL})$ were placed at room temperature. The color of the solution gradually turned from red to orange. After $1 \mathrm{~min}$, the formation of disilene 5 as a sole product was confirmed by ${ }^{1} \mathrm{H}$ NMR spectroscopy. Then $\mathrm{C}_{6} \mathrm{D}_{6}$ was removed in vacuo. After recrystallization from hexane at $-35{ }^{\circ} \mathrm{C}$ gave 5 as orange crystals $\left(18.1 \mathrm{mg}, 2.52 \times 10^{-2} \mathrm{mmol}\right)$ in $54 \%$ yield. Single crystals of 5 suitable for $X$-ray diffraction analysis were obtained by recrystallization from toluene at room temperature.

5: orange crystals; mp. $134{ }^{\circ} \mathrm{C} ;{ }^{1} \mathrm{H}$ NMR $\left(\mathrm{C}_{6} \mathrm{D}_{6}, 500 \mathrm{MHz}, 298 \mathrm{~K}\right) \delta 0.18$ (br, 9H, $\left.\mathrm{Si}\left(\mathrm{CH}_{3}\right)_{3}\right), 0.41\left(\mathrm{~s}, 9 \mathrm{H}, \mathrm{Si}\left(\mathrm{CH}_{3}\right)_{3}\right), 0.45\left(\mathrm{~s}, 18 \mathrm{H}, \mathrm{Si}\left(\mathrm{CH}_{3}\right)_{3}\right), 0.76\left(\mathrm{~s}, 9 \mathrm{H}, \mathrm{Si}\left(\mathrm{CH}_{3}\right)_{3}\right), 1.55-1.58$ $(\mathrm{m}, 1 \mathrm{H}, \mathrm{BBN}), 1.66$ (brs, $1 \mathrm{H}, \mathrm{BBN}), 1.78-2.03\left(\mathrm{~m}, 14 \mathrm{H}, \mathrm{BBN}\right.$ overlapping with $\left.\mathrm{N}\left(\mathrm{CH}_{3}\right)_{2}\right)$, 2.11-2.29 (m, 6H, BBN overlapping with $\left.\mathrm{CH}_{2} \mathrm{CHH}\right), 2.55-2.73(\mathrm{~m}, 3 \mathrm{H}, \mathrm{BBN}$ overlapping with $\mathrm{CH}_{2} \mathrm{CHH}$ ), 5.84 (brs, $2 \mathrm{H}, \mathrm{CH}$ of DMAP), 8.51 (brs, $2 \mathrm{H}, \mathrm{CH}$ of DMAP); ${ }^{13} \mathrm{C}$ NMR (toluene- $\left.d_{8}, 125 \mathrm{MHz}, 233 \mathrm{~K}\right) \delta 1.9\left(\mathrm{Si}\left(\mathrm{CH}_{3}\right)_{3}\right), 2.1\left(\mathrm{Si}\left(\mathrm{CH}_{3}\right)_{3}\right), 4.9\left(\mathrm{Si}\left(\mathrm{CH}_{3}\right)_{3}\right), 5.2\left(\mathrm{Si}\left(\mathrm{CH}_{3}\right)_{3}\right)$, $16.0(\mathrm{C}), 23.1(\mathrm{CH}), 24.7\left(\mathrm{CH}_{2}\right), 25.6\left(\mathrm{CH}_{2}\right), 27.4(\mathrm{C}), 29.8\left(\mathrm{CH}_{2}\right), 30.0\left(\mathrm{CH}_{2}\right), 34.4\left(\mathrm{CH}_{2}\right)$, $35.2\left(\mathrm{CH}_{2}\right), 35.6\left(\mathrm{CH}_{2}\right), 36.8\left(\mathrm{CH}_{2}\right), 38.0\left(\mathrm{CH}_{3}\right.$ of DMAP $), 38.2(\mathrm{CH}), 105.4(\mathrm{CH}$ of DMAP $)$, 146.5 (CH of DMAP), 153.6 (C of DMAP); $\left.{ }^{29} \mathrm{Si} \mathrm{NMR} \mathrm{(toluene-} d_{8}, 99 \mathrm{MHz}, 233 \mathrm{~K}\right) \delta-14.0$ $\left(\mathrm{Si}\left(\mathrm{CH}_{3}\right)_{3}\right),-2.1\left(\mathrm{Si}\left(\mathrm{CH}_{3}\right)_{3}\right), 0.8\left(\mathrm{Si}\left(\mathrm{CH}_{3}\right)_{3}\right), 1.3\left(\mathrm{Si}\left(\mathrm{CH}_{3}\right)_{3}\right), 2.8\left(\mathrm{Si}\left(\mathrm{CH}_{3}\right)_{3}\right), 87.9\left(=\mathrm{SiSiMe}_{3}\right)$, 195.2 (=Si(BBN.DMAP)); ${ }^{11} \mathrm{~B}$ NMR $\left(\mathrm{C}_{6} \mathrm{D}_{6}, 160 \mathrm{MHz}, 296 \mathrm{~K}\right) \delta 2.0 ; \mathrm{UV}$-vis (hexane) $\lambda_{\max } / \mathrm{nm}$ (ع) $418\left(6.0 \times 10^{3}\right), 489(\mathrm{sh})$; MS (EI, $\left.70 \mathrm{eV}\right) \mathrm{m} / \mathrm{z}(\%) 716\left(2.5, \mathrm{M}^{+}\right), 643\left(12, \mathrm{M}^{+}-\mathrm{SiMe}_{3}\right)$; Anal. Calcd for $\mathrm{C}_{34} \mathrm{H}_{73} \mathrm{BN}_{2} \mathrm{Si}_{7}$ : C, 56.93; H, 10.26; N, 3.91\%. Found: C, 57.23; H, 10.41; N, 4.03\%.

\subsection{Reaction of $\mathbf{5}$ with Triphenylborane}

In a J. Young NMR tube, $3\left(8.2 \mathrm{mg}, 1.4 \times 10^{-2} \mathrm{mmol}\right)$, DMAP $\left(2.6 \mathrm{mg}, 2.1 \times 10^{-2} \mathrm{mmol}\right)$, and $\mathrm{C}_{6} \mathrm{D}_{6}(0.5 \mathrm{~mL})$ were charged. After the formation of 5 was confirmed by a ${ }^{1} \mathrm{H}$ NMR spectrum, $\mathrm{BPh}_{3}\left(5.7 \mathrm{mg}, 2.4 \times 10^{-2} \mathrm{mmol}\right)$ was added to the mixture. The quantitative formation of 3 was confirmed by the ${ }^{1} \mathrm{H}$ NMR spectrum.

\subsection{Reaction of $\mathbf{5}$ with $\mathrm{Me}{ }_{3} \mathrm{SiCl}$}

In a J. Young NMR tube, $5\left(21.5 \mathrm{mg}, 3.0 \times 10^{-2} \mathrm{mmol}\right), \mathrm{C}_{6} \mathrm{D}_{6}(0.5 \mathrm{~mL})$ and $\mathrm{Me}_{3} \mathrm{SiCl}$ $\left(3.3 \mathrm{mg}, 3.0 \times 10^{-2} \mathrm{mmol}\right)$ were placed for $3.3 \mathrm{~h}$ at $60{ }^{\circ} \mathrm{C}$, and then Mes ${ }^{*} \mathrm{H}(11.5 \mathrm{mg}$, $4.67 \times 10^{-2} \mathrm{mmol}$ ) was added as an internal standard. The formation of disilene 1 (NMR yield $66 \%$ ) was confirmed by the ${ }^{1} \mathrm{H}$ NMR and ${ }^{29} \mathrm{Si}^{1}{ }^{1} \mathrm{H}$ 2D HMBC NMR spectra. A byproduct was a complex of 9-chloro-9-borabicyclo[3.3.1]nonane and DMAP (6), which was confirmed by the comparison of the NMR spectra with those of the authentic sample obtained alternatively from 9-chloro-9-borabicyclo[3.3.1]nonane and DMAP as follows: In a J. Young NMR tube, 9-chloro-9-borabicyclo[3.3.1]nonane (10.5 mg, 67.1 $\mu \mathrm{mol})$, DMAP $(8.6 \mathrm{mg}, 70.4 \mu \mathrm{mol})$ and $\mathrm{C}_{6} \mathrm{D}_{6}(0.5 \mathrm{~mL})$ were charged at room temperature. Removal of the volatiles and recrystallization from hexane at $-25^{\circ} \mathrm{C}$ gave 6 as a white powder $(17.5 \mathrm{mg}$, $62.8 \mu \mathrm{mol})$ in $94 \%$ yield.

6: a white powder; mp. $137-140{ }^{\circ} \mathrm{C}$ (decomp); ${ }^{1} \mathrm{H}$ NMR $\left(\mathrm{C}_{6} \mathrm{D}_{6}, 500 \mathrm{MHz}, 295 \mathrm{~K}\right)$ $\delta$ 1.58-1.63 (m, 1H, BBN), 1.68-1.76 (m, 4H, BBN), $1.94\left(\mathrm{~s}, 6 \mathrm{H}, \mathrm{CH}_{3}\right), 2.12-2.20(\mathrm{~m}, 3 \mathrm{H}$, BBN), 2.24-2.42 (m, 4H, BBN), 3.18-3.22 (m, 2H, BBN), $5.54(\mathrm{~d}, J=7.5 \mathrm{~Hz}, 2 \mathrm{H}$, aryl), 8.02 $\left(\mathrm{d}, J=7.5 \mathrm{~Hz}, 2 \mathrm{H}\right.$, aryl); ${ }^{3} \mathrm{C}$ NMR $\left(\mathrm{C}_{6} \mathrm{D}_{6}, 125 \mathrm{MHz}, 296 \mathrm{~K}\right) \delta 25.1\left(\mathrm{CH}_{2}, \mathrm{BBN}\right), 25.4\left(\mathrm{CH}_{2}\right.$, BBN), $31.9\left(\mathrm{CH}_{2}, \mathrm{BBN}\right), 32.8\left(\mathrm{CH}_{2}, \mathrm{BBN}\right), 38.4\left(\mathrm{CH}_{3}\right), 106.7$ (DMAP), 143.7 (DMAP); ${ }^{11} \mathrm{~B}$ $\operatorname{NMR}\left(\mathrm{C}_{6} \mathrm{D}_{6}, 160 \mathrm{MHz}, 296 \mathrm{~K}\right) \delta 7.4(\mathrm{BBN}) ; \mathrm{MS}(\mathrm{EI}, 70 \mathrm{eV}) \mathrm{m} / z(\%) ; 156$ (7.1, $\mathrm{M}^{+}$-dmap), 121 (100, M+ $\left.{ }^{+}-\mathrm{BBNCl}-\mathrm{H}\right)$; Anal. Calcd for $\mathrm{C}_{15} \mathrm{H}_{24} \mathrm{BClN}_{2}$ : C, 64.66; H, 8.68; N, 10.05\%. Found: $\mathrm{C}, 64.46 ; \mathrm{H}, 8.70 ; \mathrm{N}, 10.05 \%$. The ${ }^{13} \mathrm{C}$ resonance due to methine carbon nuclei next to the boron nuclei was not observed. 


\subsection{Reaction of Diboryldislene $\mathbf{4}$ with DMAP Followed by $\mathrm{Me}_{3} \mathrm{SiCl}$}

In a J. Young NMR tube, diboryldisilene $4\left(19.4 \mathrm{mg}, 3.0 \times 10^{-2} \mathrm{mmol}\right)$, DMAP $(8.2 \mathrm{mg}$, $\left.6.71 \times 10^{-2} \mathrm{mmol}\right)$, and $\mathrm{C}_{6} \mathrm{D}_{6}(0.5 \mathrm{~mL})$ were placed at room temperature. The color of the solution gradually turned from violet-blue of 4 to pink-purple. Then, $\mathrm{Me}_{3} \mathrm{SiCl}(6.56 \mathrm{mg}$, $6.04 \times 10^{-2} \mathrm{mmol}$ ) was added to the reaction mixture at room temperature and placed for $3 \mathrm{~h}$ at $60^{\circ} \mathrm{C}$. Mes* $\mathrm{H}\left(11.4 \mathrm{mg}, 4.63 \times 10^{-2} \mathrm{mmol}\right)$ was added as an internal standard. The formation of disilene 1 (NMR yield: $43 \%$ ) was confirmed by the ${ }^{1} \mathrm{H}$ and ${ }^{29} \mathrm{Si}^{1}{ }^{1} \mathrm{H}$ 2D HMBC NMR spectra.

\subsection{Single-Crystal X-ray Diffraction Analysis}

Single crystals of 3, 4, and 5 suitable for X-ray diffraction analysis were obtained by recrystallization from toluene at room temperature. For data collection, single crystals coated by Apiezon ${ }^{\circledR}$ grease were mounted on thin glass fiber and transferred into the cold nitrogen gas stream of the diffractometer. X-ray diffraction data were collected on a Bruker AXS APEX II CCD diffractometer using graphite-monochromated Mo-K $\alpha$ radiation. An empirical absorption correction based on the multiple measurements of equivalent reflections was applied using the program SADABS [29], and the structure was solved by direct methods and refined by full-matrix least-squares against $F^{2}$ using all data (SHELX-2014 or 2018) [30]. The molecular structure was analyzed using the Yadokari-XG software [31]. CCDC-2062117 to 2062119 contain the supplementary crystallographic data for this paper. These data can be obtained free of charge via http:/ / www.ccdc.cam.aC.uk/ conts/retrieving.html accessed on 2 February 2021 (or from the CCDC, 12 Union Road, Cambridge CB2 1EZ, UK; Fax: +44 1223 336033; E-mail: deposit@ccdc.cam.aC.uk).

Crystal Data for 3 (CCDC-2062117): $\mathrm{C}_{27} \mathrm{H}_{63} \mathrm{BSi}_{7}(\mathrm{M}=595.21 \mathrm{~g} / \mathrm{mol})$, triclinic, space group $P-1$ (no. 2), $a=9.2894(4) \AA, b=12.3390(5) \AA, c=17.6712(7) \AA, \alpha=76.8100(10)^{\circ}$, $\beta=88.0070(10)^{\circ}, \gamma=70.2510(10)^{\circ}, V=1854.10(13) \AA^{3}, Z=2, T=100(2) \mathrm{K}, \mu(\mathrm{MoK} \alpha)=0.273 \mathrm{~mm}^{-1}$, $D_{\text {calc }}=1.066 \mathrm{~g} / \mathrm{cm}^{3}, 27816$ reflections measured $\left(3.604^{\circ} \leq 2 \theta \leq 54.996^{\circ}\right), 8501$ unique $\left(R_{\text {int }}=0.0595, R_{\text {sigma }}=0.0624\right)$, which were used in all calculations. The final $R 1, \mathrm{w} R 2$, and GOF were $0.0462(I>2 \sigma(I)), 0.1073$ (all data), and 1.017, respectively.

Crystal Data for 4 (CCDC-2062118): $\mathrm{C}_{32} \mathrm{H}_{68} \mathrm{~B}_{2} \mathrm{Si}_{6}(\mathrm{M}=643.02 \mathrm{~g} / \mathrm{mol})$, triclinic, space group $P$-1 (no. 2), $a=12.3914(3) \AA, b=12.7560(3) \AA, c=13.8222(3) \AA, \alpha=110.7350(10)^{\circ}$, $\beta=106.9280(10)^{\circ}, \gamma=93.0890(10)^{\circ}, V=1924.43(8) \AA^{3}, Z=2, T=100(2) \mathrm{K}, \mu(\mathrm{MoK} \alpha)=0.273 \mathrm{~mm}^{-1}$, $D_{\text {calc }}=1.110 \mathrm{~g} / \mathrm{cm}^{3}, 27,816$ reflections measured $\left(3.340^{\circ} \leq 2 \theta \leq 55.000^{\circ}\right), 8836$ unique $\left(R_{\text {int }}=0.0255, R_{\text {sigma }}=0.0253\right)$, which were used in all calculations. The final $R 1, \mathrm{w} R 2$, and GOF were $0.0293(I>2 \sigma(I)), 0.0799$ (all data), and 1.017, respectively.

Crystal Data for 5 (preliminary) (CCDC 2062119): $\mathrm{C}_{34} \mathrm{H}_{73} \mathrm{BN}_{2} \mathrm{Si}_{7}(\mathrm{M}=717.38 \mathrm{~g} / \mathrm{mol})$, orthorhombic, space group $P 2{ }_{1} 2_{1} 2_{1}$ (no. 19), $a=10.1552(8) \AA, b=20.8205(14) \AA, c=20.8919(15) \AA$, $V=4417.3(6) \AA^{3}, Z=4, T=100(2) \mathrm{K}, \mu(\mathrm{MoK} \alpha)=0.273 \mathrm{~mm}^{-1}, D_{\text {calc }}=1.079 \mathrm{~g} / \mathrm{cm}^{3}, 26017$ reflections measured $\left(3.900^{\circ} \leq 2 \theta \leq 55.00^{\circ}\right), 8420$ unique $\left(R_{\text {int }}=0.0255, R_{\text {sigma }}=0.0253\right)$, which were used in all calculations. Absolute structure parameter was $0.01(6)$. The final $R 1$, $\mathrm{w} R 2$, and GOF were $0.0422(I>2 \sigma(I)), 0.0883$ (all data), and 0.950, respectively.

\subsection{Computational Study}

Theoretical calculations were performed essentially using the Gaussian 09 [32] or GRRM14 [33,34] programs. Geometry optimizations and frequency analyses of 3, 4, and 5 were carried out at the B3PW91-D3/6-31G(d) level of theory. Imaginary frequencies were not encountered in any of the optimized structures. The supplemental file "optimized_structures.xyz" contains the calculated Cartesian coordinates and energies of all molecules reported in this study. The transition energies and oscillator strengths of the electron transition in hexane (Tables $\mathrm{S} 5 \leq \mathrm{S} 8$ ) were calculated using a time-dependent hybrid DFT method (TD-DFT) at the B3LYP-D3/B1(hexane)/ / B3PW91-D3/6-31G(d) level of theory (basis B1: 6-311G(2df) [Si], 6-311G(d) [N, C, B, H]). NMR chemical shifts (Table S4) were calculated at the GIAO/B97-D3/def2-TZVP(benzene)//B3PW91-D3/6-31G(d) level 
of theory [26]. The natural bond orbital (NBO) analysis was performed at the B3PW91D3/6-31G(d) level of theory using the NBO 7.0 program [35] (Table S3).

Supplementary Materials: The following are available online. NMR spectra of compounds 3, 4, and 5 , as well as the details of theoretical study.

Author Contributions: N.A. and T.I. designed the concept. K.T. and Y.U. performed the synthesis, reactions, and characterization of new compounds. T.K., S.H. and S.I. conducted X-ray diffraction analysis. T.I. performed theoretical calculations. K.T., N.A., Y.U. and T.I. analyzed the data. K.T., Y.U. and T.I. wrote the manuscript. All authors have read and agreed to the published version of the manuscript.

Funding: This research was funded by JSPS KAKENHI grant JP24655024, JPK1513634 (T.I.), and Grant-in-Aid for JSPS Fellows (N.A.).

Institutional Review Board Statement: Not applicable.

Informed Consent Statement: Not applicable.

Data Availability Statement: The data reported in this study are available in the Supplementary Materials.

Conflicts of Interest: The authors declare no conflict of interest. The funders had no role in the design of the study, in the collection, analyses, or interpretation of data, in the writing of the manuscript, or in the decision to publish the results.

Sample Availibility: : Not applicable.

\section{References}

1. Okazaki, R.; West, R. Chemistry of Stable Disilenes. Adv. Organomet. Chem. 1996, 39, 231-273.

2. Kira, M.; Iwamoto, T. Progress in the Chemistry of Stable Disilenes. Adv. Organomet. Chem. 2006, 54, 73-148.

3. Scheschkewitz, D. Anionic Reagents with Silicon-Containing Double Bonds. Chem. Eur. J. 2009, 15, 2476-2485. [CrossRef]

4. Abersfelder, K.; Scheschkewitz, D. Synthesis of Homo- and Heterocyclic Silanes via Intermediates with Si=Si Bonds. Pure Appl. Chem. 2010, 82, 595-602. [CrossRef]

5. Scheschkewitz, D. The Versatile Chemistry of Disilenides: Disila Analogues of Vinyl Anions as Synthons in Low-Valent Silicon Chemistry. Chem. Lett. 2011, 40, 2-11. [CrossRef]

6. Iwamoto, T.; Ishida, S. Multiple Bonds with Silicon: Recent Advances in Synthesis, Structure, and Functions of Stable Disilenes. In Structure and Bonding (Berlin, Germany); Scheschkewitz, D., Ed.; Springer: Berlin/Heidelberg, Germany, 2014; Volume 156, pp. 125-202.

7. Präsang, C.; Scheschkewitz, D. Reactivity in the Periphery of Functionalised Multiple Bonds of Heavier Group 14 Elements. Chem. Soc. Rev. 2016, 45, 900-921. [CrossRef] [PubMed]

8. Rammo, A.; Scheschkewitz, D. Functional Disilenes in Synthesis. Chem. Eur. J. 2018, 24, 6866-6885. [CrossRef] [PubMed]

9. Hanusch, F.; Groll, L.; Inoue, S. Recent Advances of Group 14 Dimetallenes and Dimetallynes in Bond Activation and Catalysis. Chem. Sci. 2021, 12, 2001-2015. [CrossRef]

10. Inoue, S.; Ichinohe, M.; Sekiguchi, A. An Isolable Boryl-substituted Disilene from the Reaction of an sp2-type Silyl Anion with Haloboranes: Synthesis and Characterization. Chem. Lett. 2008, 37, 1044-1045. [CrossRef]

11. Takeuchi, K.; Ikoshi, M.; Ichinohe, M.; Sekiguchi, A. Addition of Amines and Hydroborane to the Disilyne RSi $\equiv$ SiR (R = SiiPr[CH(SiMe3)2]2) Giving Amino- and Boryl-substituted Disilenes. J. Am. Chem. Soc. 2010, 132, 930-931. [CrossRef] [PubMed]

12. Takeuchi, K.; Ichinohe, M.; Sekiguchi, A. Hydroboration of Disilyne RSi $\equiv \operatorname{SiR}(\mathrm{R}=\operatorname{SiiPr}[\mathrm{CH}(\mathrm{SiMe}) 2] 2)$, Giving Boryl-Substituted Disilenes. Organometallics 2011, 30, 2044-2050. [CrossRef]

13. Kosai, T.; Iwamoto, T. Stable Push-Pull Disilene: Substantial Donor-Acceptor Interactions through the Si=Si Double Bond. J. Am. Chem. Soc. 2017, 139, 18146-18149. [CrossRef] [PubMed]

14. Kosai, T.; Iwamoto, T. Cleavage of Two Hydrogen Molecules by Boryldisilenes. Chem. Eur. J. 2018, 24, 7774-7780. [CrossRef]

15. Sarkar, S.K.; Chaliha, R.; Siddiqui, M.M.; Banerjee, S.; Munch, A.; Herbst-Irmer, R.; Stalke, D.; Jemmis, E.D.; Roesky, H.W. A Neutral Three-Membered $2 \pi$ Aromatic Disilaborirane and the Unique Conversion into a Four-Membered BSi2N-Ring. Angezw. Chem. Int. Ed. 2020, 59, 23015-23019. [CrossRef] [PubMed]

16. Liu, Z.; Zhang, J.; Yang, H.; Cui, C. Synthesis of Boryl-Substituted Disilane, Disilene, and Silyl Cation. Organometallics 2020, 39, 4164-4168. [CrossRef]

17. Tian, M.; Zhang, J.; Yang, H.; Cui, C. Isolation of a 1-Magnesium-2,3-disilacyclopropene and a Related Bis(disilenide). J. Am. Chem. Soc. 2020, 142, 4131-4135. [CrossRef] [PubMed] 
18. Akasaka, N.; Fujieda, K.; Garoni, E.; Kamada, K.; Matsui, H.; Nakano, M.; Iwamoto, T. Synthesis and Functionalization of a 1,4-Bis(trimethylsilyl)tetrasila-1,3-diene through the Selective Cleavage of Si(sp2)-Si(sp3) Bonds under Mild Reaction Conditions. Organometallics 2018, 37, 172-175. [CrossRef]

19. Akasaka, N.; Tanaka, K.; Ishida, S.; Iwamoto, T. Synthesis and Functionalization of a 1,2-Bis(trimethylsilyl)-1,2-disilacyclohexene That Can Serve as a Unit of cis-1,2-Dialkyldisilene. Inorganics 2018, 6, 21. [CrossRef]

20. Kawachi, A.; Minamimoto, T.; Tamao, K. Boron-Metal Exchange Reaction of Silylboranes with Organometallic Reagents: A New Route to Arylsilyl Anions. Chem. Lett. 2001, 30, 1216-1217. [CrossRef]

21. O'Brien, J.M.; Hoveyda, A.H. Metal-free Catalytic C-Si Bond Formation in an Aqueous Medium. Enantioselective NHC-catalyzed Silyl Conjugate Additions to Cyclic and Acyclic $\alpha, \beta$-Unsaturated Carbonyls. J. Am. Chem. Soc. 2011, 133, $7712-7715$.

22. Ito, H.; Horita, Y.; Yamamoto, E. Potassium tert-Butoxide-mediated Regioselective Silaboration of Aromatic Alkenes. Chem. Commun. 2012, 48, 8006-8008. [CrossRef]

23. Cui, B.; Jia, S.; Tokunaga, E.; Shibata, N. Defluorosilylation of Fluoroarenes and Fluoroalkanes. Nat. Commun. 2018, 9, 4393. [CrossRef] [PubMed]

24. Shishido, R.; Uesugi, M.; Takahashi, R.; Mita, T.; Ishiyama, T.; Kubota, K.; Ito, H. General Synthesis of Trialkyl- and Dialkylarylsilylboranes: Versatile Silicon Nucleophiles in Organic Synthesis. J. Am. Chem. Soc. 2020, 142, 14125-14133. [CrossRef] [PubMed]

25. Zirngast, M.; Flock, M.; Baumgartner, J.; Marschner, C. Formation of Formal Disilene Fluoride Adducts. J. Am. Chem. Soc. 2008, 130, 17460-17470. [CrossRef]

26. Bursch, M.; Gasevic, T.; Stuckrath, J.B.; Grimme, S. Comprehensive Benchmark Study on the Calculation of ${ }^{29}$ Si NMR Chemical Shifts. Inorg. Chem. 2021, 60, 272-285. [CrossRef] [PubMed]

27. Auer, D.; Strohmann, C.; Arbuznikov, A.V.; Kaupp, M. Understanding Substituent Effects on ${ }^{29}$ Si Chemical Shifts and Bonding in Disilenes. A Quantum Chemical Analysis. Organometallics 2003, 22, 2442-2449.

28. Brown, H.C.; Kulkarni, S.U. Organoboranes. J. Organomet. Chem. 1979, 168, 281-293. [CrossRef]

29. Sheldrick, G.M. SADABS, Program for Empirical Absorption Correction; University of Gottingen: Gottingen, Germany, 1996.

30. Sheldrick, G.M. Crystal structure refinement with SHELXL. Acta Crystallogr. C Struct. Chem. 2015, 71 Pt 1, 3-8. [CrossRef]

31. Kabuto, C.; Akine, S.; Nemoto, T.; Kwon, E. Release of Software (Yadokari-XG 2009) for Crystal Structure Analyses. J. Cryst. Soc. Jpn. 2009, 51, 218-224.

32. Frisch, M.J.; Trucks, G.W.; Schlegel, H.B.; Scuseria, G.E.; Robb, M.A.; Cheeseman, J.R.; Scalmani, G.; Barone, V.; Mennucci, B.; Petersson, G.A.; et al. Gaussian 09, Revision E.01; Gaussian, Inc.: Wallingford, CT, USA, 2009.

33. Maeda, S.; Harabuchi, Y.; Osada, Y.; Taketsugu, T.; Morokuma, K.; Ohno, K. Available online: https:/ /iqce.jp/GRRM/ (accessed on 2 February 2021).

34. Maeda, S.; Ohno, K.; Morokuma, K. Systematic Exploration of the Mechanism of Chemical Reactions: The Global Reaction Route Mapping (GRRM) Strategy Using the ADDF and AFIR Methods. Phys. Chem. Chem. Phys. 2013, 15, 3683-3701. [CrossRef]

35. Glendening, E.D.; Badenhoop, J.K.; Reed, A.E.; Carpenter, J.E.; Bohmann, J.A.; Morales, C.M.; Karafiloglou, P.; Landis, C.R.; Weinhold, F. NBO 7.0. Theoretical Chemistry Institute; University of Wisconsin: Madison, WI, USA, 2018. 